\begin{tabular}{ll|l} 
Case Reports in & \multicolumn{2}{c}{ Case Rep Gastroenterol 2013;7:340-346 } \\
\cline { 2 - 3 } Gastroenterology & $\begin{array}{l}\text { DOI: 10.1159/000354725 } \\
\text { Published onlne: August 16, 2013 }\end{array}$ & $\begin{array}{l}\text { ○ 2013 S. Karger AG, Basel } \\
\text { www.karger.com/crg }\end{array}$ \\
\hline & $\begin{array}{l}\text { This is an Open Access article licensed under the terms of the Creative Commons } \\
\text { Attribution-NonCommercial 3.0 Unported license (CC BY-NC) (www.karger.com/OA- } \\
\text { license), applicable to the online version of the article only. Distribution permitted for non- } \\
\text { commercial purposes only. }\end{array}$
\end{tabular}

\title{
A Case of Adult Type 1 Gaucher Disease Complicated by Temporal Intestinal Hemorrhage
}

\author{
Junitsu Ito ${ }^{a}$ d Takafumi Saito $^{a}$ Chikahiko Numakura $^{b}$ Akiko Iwaba $^{c}$ \\ Shinpei Sugahara ${ }^{a}$ Rika Ishii $^{a}$ Chikako Sato $^{a}$ Hiroaki Haga $^{a}$ \\ Kazuo Okumoto ${ }^{a}$ Yuko Nishise ${ }^{a}$ Hisayoshi Watanabe ${ }^{a}$ Hiroyuki Ida $^{f}$

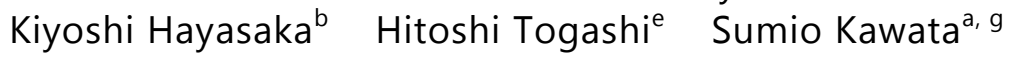 \\ Yoshiyuki Ueno ${ }^{a}$
}

Departments of ${ }^{a}$ Gastroenterology, ${ }^{b}$ Pediatrics and ${ }^{c}$ Diagnostic Pathology, Faculty of Medicine, ${ }^{d}$ Department of Biochemistry and Molecular Biology, Graduate School of Medical Science, and ${ }^{\mathrm{e}} \mathrm{Health}$ Administrative Center, Yamagata University, Yamagata; ${ }^{f}$ Department of Pediatrics, Jikei University School of Medicine, Tokyo; ${ }^{9}$ Hyogo Prefectural Nishinomiya Hospital, Nishinomiya, Japan

\section{Key Words}

Gaucher disease type $1 \cdot$ Rectal hemorrhage $\cdot$ Thrombocytopenia $\cdot$ L444P/D409H

\begin{abstract}
A 21-year-old man with a history of sudden rectal hemorrhage was referred to our hospital. Examination disclosed thrombocytopenia and hepatosplenomegaly. A liver biopsy specimen demonstrated Gaucher cells in Glisson's capsule. Additional investigations revealed a low level of leukocyte $\beta$-glucosidase activity and common mutations of the glucocerebrosidase gene, L444P/D409H. We diagnosed the patient with Gaucher disease type 1. He underwent enzyme replacement therapy. Thrombocytopenia and hepatosplenomegaly improved at a rate of approximately 50 and 20\%, respectively, within 6 months. This case suggests that we must pay attention to adult Gaucher disease as a differential diagnosis for cryptogenic thrombocytopenia.

(C) 2013 S. Karger AG, Basel
\end{abstract}

\section{Introduction}

Gaucher disease is a glucosylceramide lipidosis caused by deficient acid $\beta$-glucosidase (glucocerebrosidase, GBA; EC 3.2.1.45) enzymatic activity mainly due to $G B A$ gene mutations,

Dr. Junitsu Ito

Department of Biochemistry and Molecular Biology

Graduate School of Medical Science, Yamagata University

2-2-2 Iida-Nishi, Yamagata City, Yamagata 990-9585 (Japan)

E-Mail jxi9@med.id.yamagata-u.ac.jp 
Ito et al.: A Case of Adult Type 1 Gaucher Disease Complicated by Temporal Intestinal Hemorrhage

inherited as an autosomal recessive trait [1-3]. GBA catalyzes the hydrolysis of glucosylceramide into glucose and ceramide. Excess accumulation of glucosylceramide within macrophages in various tissues leads to clinical manifestations. Gaucher disease has been classified into three types according to clinical symptoms: non-neuronopathic (type 1), acute neuronopathic (type 2) and subacute neuronopathic (type 3). Type 1 is the most common variant and characterized by relatively later onset and slower progress than the neuronopathic types. Its common symptoms include hepatosplenomegaly, thrombocytopenia due to hypersplenism and bone manifestations. While bleeding complications can be caused as a result of thrombocytopenia, spontaneous intestinal bleeding is extremely rare.

We describe a patient with type 1 Gaucher disease who was diagnosed with the disease by chance because of spontaneous intestinal hemorrhage.

\section{Case Report}

A 21-year-old male patient suffering from sudden rectal hemorrhage was admitted to a general hospital in July 2009. Emergent colonoscopy was performed with the findings of (1) a large amount of blood in the rectum and sigmoid colon and (2) oozing from eroded rectal mucosa. Laboratory investigation revealed thrombocytopenia (platelets $10.3 \times 10^{4}$ / $\mu \mathrm{l})$. Although the hemorrhage stopped spontaneously and did not occur again, the patient was referred to our hospital for further examinations. He had had no previous significant rectal bleeding. His past medical history was unremarkable except for occasional nasal bleeding during childhood.

On physical examination, the abdomen was soft and flat; a non-tender liver edge descended to $8.5 \mathrm{~cm}$ below the right costal margin, and the splenic tip was palpable $11.5 \mathrm{~cm}$ below the left costal margin. Neurologic examination revealed no evidence of abnormalities. The laboratory data are summarized in table 1 . There were thrombocytopenia and slight leukocytopenia (platelets $6.7 \times 10^{4} / \mu \mathrm{l}$, white blood cells $3,180 / \mu \mathrm{l}$ ). Other laboratory findings disclosed: total bilirubin $1.4 \mathrm{mg} / \mathrm{dl}$ (reference range $0.2-1.3$ ), direct bilirubin $0.5 \mathrm{mg} / \mathrm{dl}$ (reference range $0-0.3$ ), and prothrombin time activity $77.0 \%$ (reference range 90-130). To find out the cause of thrombocytopenia and leukocytopenia, we performed serology tests for infection with hepatitis B virus, hepatitis C virus, Epstein-Barr virus and Helicobacter pylori; however, there were no remarkable findings. Anti-DNA antibody test showed a titer of 1:40 (reference range $<1: 40$ ). His platelet-associated immunoglobulin G (PAIgG) level was elevated to $166 \mathrm{ng} / 10^{7}$ cells (reference range 9.0-25.0), however anti-platelet antibody (antiplatelet-binding IgG) was negative.

Enhanced computed tomography (CT) showed the extremely enlarged liver and spleen. The splenic and the superior mesenteric vein were dilated and tortuous, whereas no apparent cirrhotic change of the liver was observed (fig. 1a). For further examination, especially for the differential diagnosis of idiopathic portal hypertension, we performed a liver biopsy. The liver biopsy specimen showed that numerous large cells with striated cytoplasm assembled in Glisson's capsule (fig. 2). The cells had abundant eosinophilic cytoplasm with a striated or fibrillar appearance like that of crumpled tissue paper, which is typical of Gaucher cells [4]. There was fibrous expansion of most portal tract areas, but bridging fibrosis was not seen. Additional blood investigations revealed high values of acid phosphatase and angiotensin-converting enzyme (ACE) concentrations (table 1), which is compatible with Gaucher disease [5]. The enzymatic activity of leukocyte $\beta$-glucosidase, the measurement of which is necessary for the definitive diagnosis of Gaucher disease, had decreased to $11.67 \mathrm{nmol} / \mathrm{h} / \mathrm{mg}$ (reference range 56.76-74.85) [6, 7]. We analyzed the seven common 


\begin{tabular}{l|l}
\hline DOI: $10.1159 / 000354725$ & $\begin{array}{l}\text { C } 2013 \text { S. Karger AG, Basel } \\
\text { www.karger.com/crg }\end{array}$ \\
\hline
\end{tabular}

Ito et al.: A Case of Adult Type 1 Gaucher Disease Complicated by Temporal Intestinal Hemorrhage

mutations (N370S, 84GG, F213I, IVS2+1, L444P, R463C and D409H) in the GBA gene as previously reported [8-10] with the informed consent of the patient and found the compound heterozygous mutations L444P/D409H. Based on these results, we diagnosed the patient with Gaucher disease type 1.

We started enzyme replacement therapy (ERT). $60 \mathrm{U} / \mathrm{kg}$ body weight imiglucerase, a macrophage-targeted recombinant human glucocerebrosidase, was injected every 2 weeks [11]. Figure $1 \mathrm{~b}$ shows the CT scan 5 months after ERT started. The liver and the spleen were sized down (liver: from $23.3 \times 15.4 \times 20.3 \mathrm{~cm}$ to $22.1 \times 15.3 \times 17.9 \mathrm{~cm}$; spleen: from $12.8 \times$ $10.5 \times 21.1 \mathrm{~cm}$ to $11.8 \times 9.4 \times 17.3 \mathrm{~cm}$ ). Platelet counts number and ACE concentration, a biomarker of the progress of Gaucher disease [5], were also improved from 7.4 to $11.3 \times$ $10^{4} / \mu \mathrm{l}$ and from 42.5 to $24.7 \mathrm{IU} / \mu \mathrm{l}$, respectively (fig. 3).

\section{Discussion}

Gaucher disease patients are generally diagnosed by symptoms of hepatosplenomegaly or bone disease in childhood, whereas lesser degrees of hepatosplenomegaly occur in adults $[2,3]$. It is extremely rare that a patient with type 1 Gaucher disease is diagnosed by chance because of spontaneous intestinal hemorrhage.

Some reports have described hemorrhagic complications as one of the clinical features of Gaucher disease, which is mostly associated with thrombocytopenia due to splenomegaly or esophageal varices due to liver cirrhosis. Hemorrhage of the stomach or intestine is uncommon; a few cases of gastrointestinal hemorrhage associated with gastric ulcer [12] or ileal lymphoid hyperplasia [13] have been reported.

In the present case, the patient did not have esophageal varices and hemorrhage was recognized at the rectum and sigmoid colon. The endoscopic biopsy specimen of rectal epithelium showed neither particular etiological features leading to hemorrhage nor Gaucher cells (data not shown). It is difficult to identify the clear cause of sudden colorectal hemorrhage. However, CT images showed that the splenic and the superior mesenteric vein were dilated and tortuous, suggesting portal hypertension. It is possible that portal hypertension due to liver enlargement participated in leading to rectal and colonic hemorrhage in the present case. The number of platelets immediately after sudden rectal hemorrhage was $10.3 \times 10^{4} / \mu \mathrm{l}$, which seems not enough to lead to hemorrhage. However, another possible candidate for the etiology of sudden hemorrhage is abnormality of platelet function. Keisey et al. [14] reported two Gaucher disease patients complicating pseudo-pseudo BernardSoulier syndrome despite normalization of platelets counts after spleen removal. Concerning PAIgG, Lester et al. [15] reported the occurrence of a high level of PAIgG in a case of Gaucher disease with concurrent immune thrombocytopenic purpura. Although anti-platelet antibody was negative, the PAIgG level was elevated in the present case (table 1). The possibility that PAIgG causes thrombocytopenia and a platelet function disorder is not excluded.

Treatments for Gaucher disease to be considered are reported to be ERT, splenectomy and bone marrow transplantation [6, 7]. We started ERT in our patient and the therapy was very effective. The number of platelets increased at a rate of 53\%, and the size of both liver and spleen decreased at the rate of roughly $20 \%$ within 6 months.

Patients with type 1 Gaucher disease generally do not have neuropathic symptoms and lesser degrees of hepatosplenomegaly when their symptoms appear in adulthood. Thus, the adult type 1 Gaucher disease patient without bone disease, as in the current case, has poor presentation of specific symptoms, resulting in the disease being difficult to find unless a special event like hemorrhage occurs. In conclusion, although Gaucher disease tends to be 


\begin{tabular}{l|l}
\hline DOI: $10.1159 / 000354725$ & $\begin{array}{l}\text { C } 2013 \text { S. Karger AG, Basel } \\
\text { www.karger.com/crg }\end{array}$ \\
\hline
\end{tabular}

Ito et al.: A Case of Adult Type 1 Gaucher Disease Complicated by Temporal Intestinal Hemorrhage

considered as a pediatric disease, we have to pay attention to adult Gaucher disease as a differential diagnosis for cryptogenic thrombocytopenia.

\section{Disclosure Statement}

The authors disclose possible conflicts of interest with Genzyme Japan K.K.

\section{References}

1 Brady RO, Kanfer J, Shapiro D: The metabolism of glucocerebrosides. I. Purification and properties of a glucocerebroside-cleaving enzyme from spleen tissue. J Biol Chem 1965;240:39-43.

-2 Grabowski GA: Phenotype, diagnosis, and treatment of Gaucher's disease. Lancet 2008;372:1263-1271.

-3 Charrow J, Andersson HC, Kaplan P, Kolodny EH, Mistry P, Pastores G, Rosenbloom BE, Scott CR, Wappner RS, Weinreb NJ, Zimran A: The Gaucher registry: demographics and disease characteristics of 1,698 patients with Gaucher disease. Arch Intern Med 2000;160:2835-2843.

4 Larsen EC, Connolly SA, Rosenberg AE: Case records of the Massachusetts General Hospital. Weekly clinicopathological exercises. Case 20-2003. A nine-year-old girl with hepatosplenomegaly and pain in the thigh. N Engl J Med 2003;348:2669-2677.

-5 Cabrera-Salazar MA, O’Rourke E, Henderson N, Wessel H, Barranger JA: Correlation of surrogate markers of Gaucher disease. Implications for long-term follow up of enzyme replacement therapy. Clin Chim Acta 2004;344:101-107.

6 Cox TM: Gaucher disease: clinical profile and therapeutic developments. Biologics 2010;4:299-313.

7 Zimran A: How I treat Gaucher disease. Blood 2011;118:1463-1471.

8 Ida H, Rennert OM, Kawame H, Ito T, Maekawa K, Eto Y: Mutation screening of Japanese patients with neuropathic Gaucher disease. Hum Genet 1996;98:167-171.

-9 Kawame H, Maekawa K, Eto Y: Molecular screening of Japanese patients with Gaucher disease: phenotypic variability in the same genotypes. Hum Mutat 1993;2:362-367.

10 Beutler E: Gaucher disease: new molecular approaches to diagnosis and treatment. Science 1992;256: 794-799.

11 Grabowski GA, Barton NW, Pastores G, Dambrosia JM, Banerjee TK, McKee MA, Parker C, Schiffmann R, Hill SC, Brady RO: Enzyme therapy in type 1 Gaucher disease: comparative efficacy of mannose-terminated glucocerebrosidase from natural and recombinant sources. Ann Intern Med 1995;122:33-39.

$\$ 12$ Hoffmann B, Schwahn B, Knobbe CB, Vogel M, Mayatepek E, Wendel U: Acute neuronopathic Gaucher disease complicated by fatal gastrointestinal bleeding. Neuropediatrics 2006;37:163-165.

13 Hoffman JJ, Downie R, Haqqani M: Massive gastrointestinal haemorrhage associated with ileal lymphoid hyperplasia in Gaucher's disease. Postgrad Med J 1991;67:479-481.

$\checkmark 14$ Keisey H, Christopoulos C, Gray AA, Machin SJ: Acquired pseudo-pseudo Bernard-Soulier syndrome complicating Gaucher's disease. J Clin Pathol 1994;47:162-165.

-15 Lester TJ, Grabowski GA, Goldblatt J, Leiderman IZ, Zaroulis CG: Immune thrombocytopenia and Gaucher's disease. Am J Med 1984;77:569-571. 
Ito et al.: A Case of Adult Type 1 Gaucher Disease Complicated by Temporal Intestinal Hemorrhage

Table 1. Laboratory data

\begin{tabular}{ll} 
Hematology & \\
White blood cells & $3,180 / \mu \mathrm{l}$ \\
Hemoglobin & $14.0 \mathrm{mg} / \mathrm{dl}$ \\
Platelets & $6.7 \times 10^{4} / \mu \mathrm{l}$ \\
\hline Blood chemistry & \\
Total bilirubin & $1.4 \mathrm{mg} / \mathrm{dl}$ \\
Direct bilirubin & $0.5 \mathrm{mg} / \mathrm{dl}$ \\
AST & $19 \mathrm{U} / \mathrm{l}$ \\
ALT & $17 \mathrm{U} / \mathrm{l}$ \\
Alkaline phosphatase & $213 \mathrm{U} / \mathrm{l}$ \\
$\gamma$-GTP & $22 \mathrm{U} / \mathrm{l}$ \\
Total protein & $7.6 \mathrm{~g} / \mathrm{dl}$ \\
Albumin & $4.8 \mathrm{~g} / \mathrm{dl}$ \\
Immunoglobulin G & $1,580 \mathrm{mg} / \mathrm{dl}$ \\
Immunoglobulin A & $272 \mathrm{mg} / \mathrm{dl}$ \\
Immunoglobulin M & $146 \mathrm{mg} / \mathrm{dl}$ \\
\hline Coagulation & \\
PT\% & $77.0 \%$ \\
\hline Serology test & \\
HBs-Ag & negative \\
HCV-Ab & negative \\
Anti-nuclear antibody & negative \\
Anti-mitochondrial M2 antibody & negative \\
EBV-VCA IgM & negative \\
EBV-VCA IgG & $80+$ \\
EBNA & $80+$ \\
Anti-platelet antibody & negative \\
PAIgG & $166 \mathrm{ng} / 107 \mathrm{cells}$ \\
Anti-DNA antibody & $40+$ \\
Anti-H. pylori antibody IgG & negative \\
\hline Others & \\
Acid phosphatase (8.3-21.4) & $26.3 \mathrm{U} / \mathrm{l}$ \\
ACE (<14.4) & $42.5 \mathrm{IU} / \mu \mathrm{l}$ \\
Leukocyte $\beta$-glucosidase (56.76-74.85) & $11.67 \mathrm{nmol} / \mathrm{h} / \mathrm{mg}$ \\
\hline
\end{tabular}

ALT = Alanine aminotransferase; AST = aspartate aminotransferase; EBNA = Epstein-Barr virus nuclear antigen; EBV-VCA IgG = EpsteinBarr virus-viral capsid antigen antibody immunoglobulin G; EBV-VCA IgM = Epstein-Barr virus-viral capsid antigen antibody immunoglobulin M; $\gamma$-GTP = gamma-glutamyl transpeptidase; $\mathrm{HBs}-\mathrm{Ag}=$ hepatitis B surface antigen; HCV-Ab = hepatitis $\mathrm{C}$ virus antibody; $\mathrm{PT} \%=$ prothrombin time activity. 
Ito et al:: A Case of Adult Type 1 Gaucher Disease Complicated by Temporal Intestinal Hemorrhage

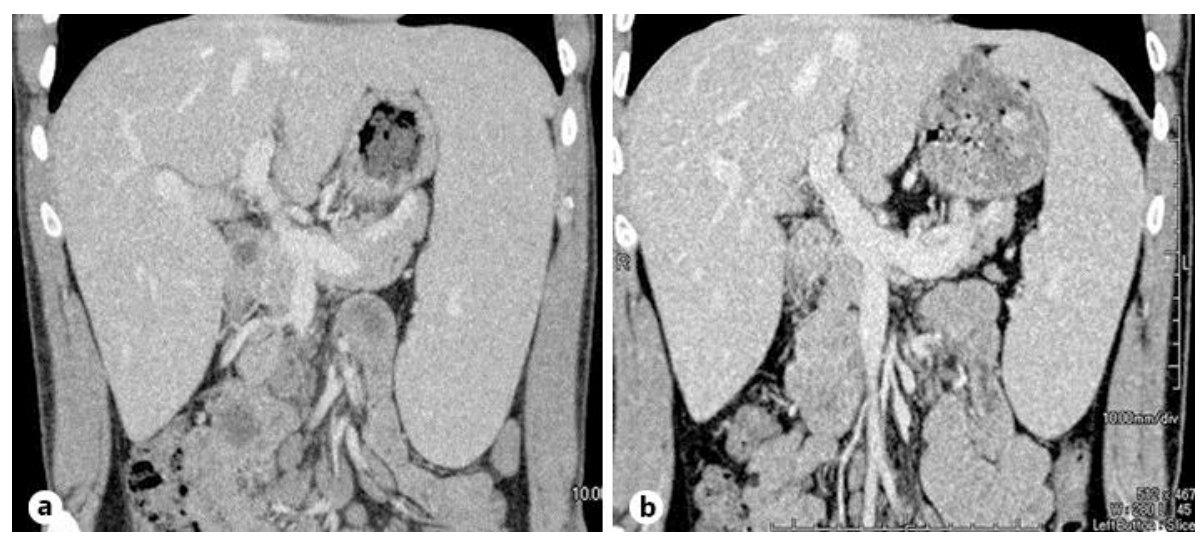

Fig. 1. Abdominal CT images. a Before ERT. Liver size: $23.3 \times 15.4 \times 20.3 \mathrm{~cm}$. Spleen size: $12.8 \times 10.5 \times$ $21.1 \mathrm{~cm}$. b 5 months after ERT started. Liver size: $22.1 \times 15.3 \times 17.9 \mathrm{~cm}$. Spleen size: $11.8 \times 9.4 \times 17.3 \mathrm{~cm}$.

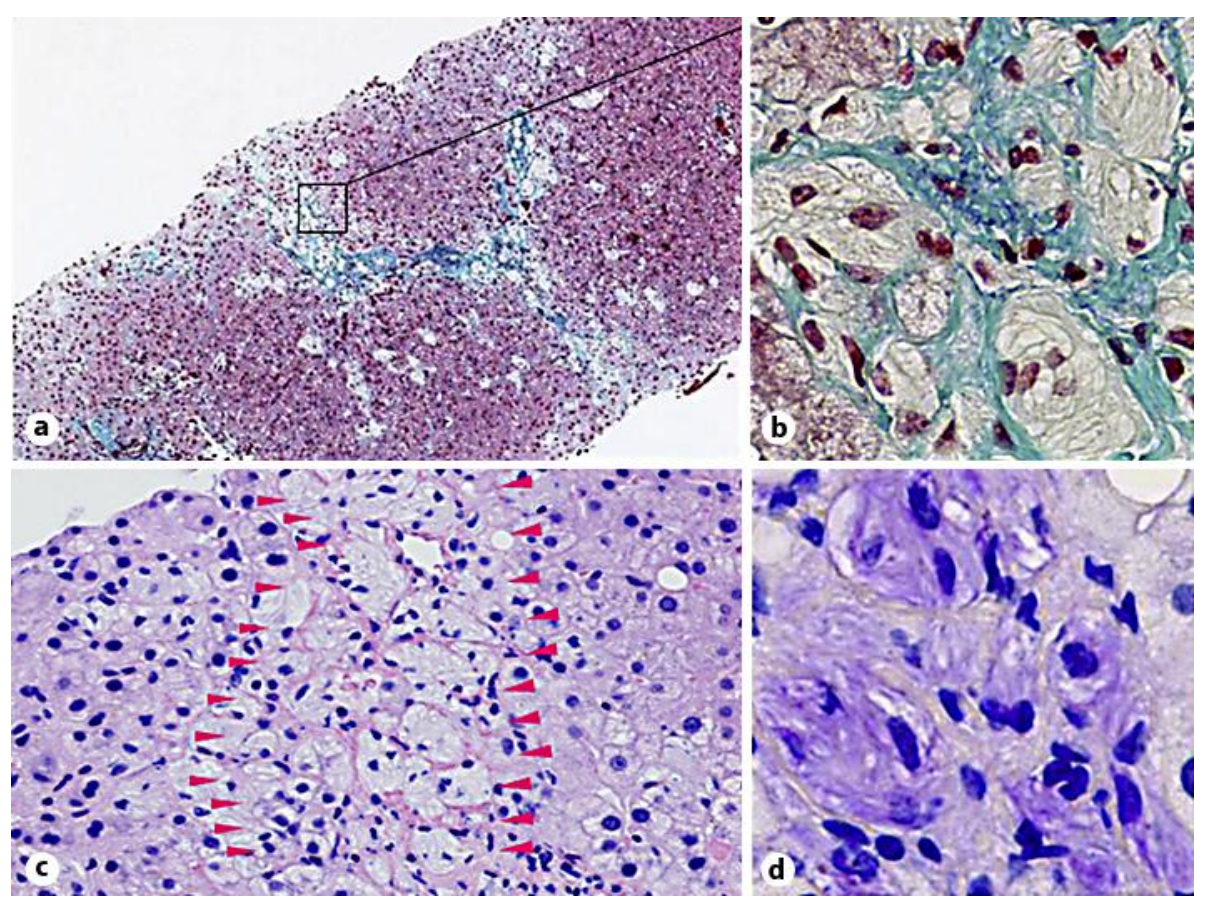

Fig. 2. Microscopic findings of liver biopsy specimen. a, b Gaucher cells in Glisson's capsule (ElasticaMasson, $\mathbf{a} \times 40, \mathbf{b} \times 400$ ). $\mathbf{c}$ Arrowheads indicate the assembly of Gaucher cells in Glisson's capsule (hematoxylin and eosin, $\times 200)$. $\mathbf{d}$ The cytoplasm of Gaucher cells is well stained with periodic acid-Schiff $(\times 400)$. 
Ito et al.: A Case of Adult Type 1 Gaucher Disease Complicated by Temporal Intestinal Hemorrhage

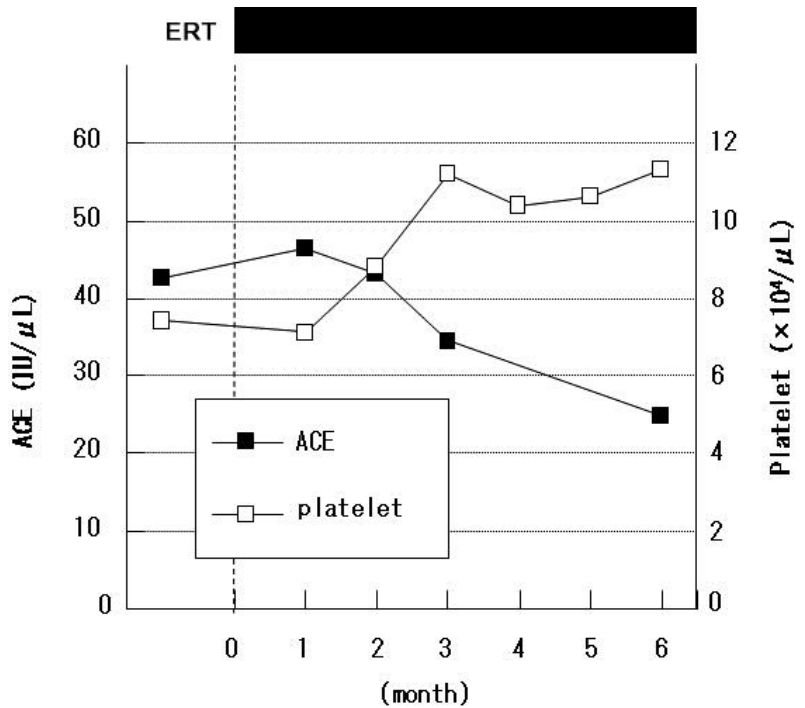

Fig. 3. Changes in platelets count and ACE concentration during the course of ERT. 